\title{
MIXED LIGAND COMPLEX OF LANTHANUM(III) AND ALIZARINE-COMPLEXONE WITH FLUORIDE IN MICELLAR MEDIUM FOR SPECTROPHOTOMETRIC DETERMINATION OF TOTAL FLUORINE
}

\author{
Alexander Chebotarev ${ }^{1}$, Anhelina Demchuk ${ }^{1}$, Kateryna Bevziuk $^{1}$, Denys Snigur ${ }^{1, 凶}$
}

https://doi.org/10.23939/chcht14.01.001

\begin{abstract}
A technique for direct spectrophotometric determination of total fluorine in products for oral hygiene using a mixed ligand complex $\mathrm{La}(\mathrm{III})$ and alizarincomplexone with fluoride ion in the presence of a non-ionic surfactant has been developed. A number of complexes of different stoichiometry formed in the system has been found. The La:alizarin-complexone: $\mathrm{F}^{-}=1: 2: 1$ complex was shown to be used as an analytical form. The complex in the presence of Tween 80 is characterized by the molar absorptivity $\varepsilon_{620}=11000 \mathrm{~mol} \cdot \mathrm{dm}^{-3} \cdot \mathrm{cm}^{-1}$. The calibration curve is linear in the concentration range of fluoride ions $0.06-0.5 \mu \mathrm{g} / \mathrm{ml}$. A simple, rapid, sensitive, and green procedure for the spectrophotometric determination of $\mathrm{F}^{-}$ using lanthanum alizarin-complexonate in the presence of Tween 80 was proposed and this technique was tested on samples of toothpastes and mouth rinses.
\end{abstract}

Keywords: spectrophotometry, alizarin-complexone, mixed ligand complex, total fluoride, Tween 80 .

\section{Introduction}

Along with the application of the ionometric method for determination of fluoride ions, spectrophotometric methods are used for the same purposes, which is associated with the instability of the operation of the fluoride-selective electrode. The ionometric determination of fluoride ions is possible in the concentration range from $10^{-4}$ to $\left(10^{-6}-10^{-7}\right) \mathrm{M}$ (depending on the type of electrode and the conditions for the determination), and its selectivity decreases in the presence of hydroxyl, citrate and oxalate ions. In addition, the precision of ionometric determination of fluorides is determined by the quality of the fluoride-selective electrode and the sensitivity of the potentiometric apparatus [1-5]. The main approaches to

\footnotetext{
${ }^{1}$ Odesa I.I. Mechnikov National University,

2, Dvoryanskaya St., 65082 Odesa, Ukraine

270892denis@gmail.com

(C) Chebotarev A., Demchuk A., Bevziuk K., Snigur D., 2020
}

the spectrophotometric determination of fluorides are based on their ability to form simple and mixed ligand complexes with a number of $d$ - and $p$-elements, but most of them are indirect [6]. In reactions with colored complexes of certain high-charge metal ions, for example, $\mathrm{Zr}(\mathrm{IV}), \mathrm{Th}(\mathrm{IV}), \mathrm{Fe}(\mathrm{III}), \mathrm{Al}(\mathrm{III})$ and $\mathrm{Ti}(\mathrm{IV})$ fluoride ions bind the above ions to strong colorless complexes. For indirect spectrophotometric determination of fluorides, $\mathrm{Zr}$ (IV) complexes with eriochromocyanine $\left(\mathrm{pH} 1, \lambda_{\max }=\right.$ $=545 \mathrm{~nm})$, solochromocyanine $\mathrm{P}(0.05 \mathrm{M} \mathrm{HCI}, \lambda=$ $=545 \mathrm{~nm}$ ) and other reagents are used [6]. In all cases, the determination of $\mathrm{F}^{-}$is prevented by sulfates (form complexes with $\mathrm{Zr}$ ) and metal ions, which form strong fluoride complexes. It was found that the most sensitive to $\mathrm{F}^{-}$are thorium complexes with eriochromcyanine $\mathrm{P}$, xylenol orange, methylene blue, stilbazo. Nevertheless, the most simple and sensitive are the direct spectrophotometric methods for determining fluorides. A number of reagents are described that form colored complex compounds directly with fluoride ions [8-13]. For selective detection of fluorides, optical sensors based on pyrazolone derivatives are proposed, where $\mathrm{F}^{-}$binds to the reagent through the hydrazine functional group due to hydrogen bonds to form an intensely colored compound [8]. However, these analytical forms could not be applied in practice. To date, for direct spectrophotometric determination of $\mathrm{F}^{-}$in many cases, mixed ligand complexes are used, among which the complexes of lanthanides with alizarin-complexone were most widely used $[14,15]$. Meanwhile, the difference between the information on the optimal conditions for complex formation and analytical definition should be noted [6]. In addition, the formation of a mixed ligand complex in the $\mathrm{AC}-\mathrm{La}(\mathrm{III})-\mathrm{F}$ system is long in time, the color of the analytical form is not stable, which requires the introduction of organic solvents (acetone, dimethylformamide) or reaction on the surface of the solid phase, in particular, modified silica [16]. Surfactants are able to act 
as sufficiently universal modifiers of the physico-chemical properties of polydentant chelating agents. The use of surfactant micelles as environmentally friendly nanoreactors allows not only increasing the stability of complex compounds, but also leads to an increase in the intensity of their light absorption [17]. To the best of our knowledge, the use of surfactants to improve the analytical characteristics of alizarin-complexone mixed ligand complexes for the determination of fluorides is not described in the literature.

Thus, the aim of this work is to develop a technique for direct spectrophotometric determination of total fluorine in products for oral hygiene using a mixed ligand complex $\mathrm{La}(\mathrm{III})$ and alizarin-complexone with fluoride ion in the presence of a non-ionic surfactant.

\section{Experimental}

\subsection{Reagents}

A freshly prepared working solution alizarincomplexone with the concentration of $1 \cdot 10^{-3} \mathrm{~mol} \cdot \mathrm{dm}^{-3}$ was prepared by dissolving the exact sample of the reagent in distilled water. A solution of $\mathrm{La}$ (III) $\left(1 \cdot 10^{-2} \mathrm{~mol} \cdot \mathrm{dm}^{-3}\right)$ was prepared by dissolving a sample of lanthanum(III) nitrate in $0.1 \mathrm{~mol} \cdot \mathrm{dm}^{-3} \mathrm{HNO}_{3}$ and standardized complexometrically [18]. To stabilize the complexes in solution, a nonionic surfactant Tween 80 with the concentration of $1 \cdot 10^{-3} \mathrm{~mol} \cdot \mathrm{dm}^{-3}$ was used. Solutions with lower concentrations were prepared by diluting the starting materials. The necessary acidity was maintained with the help of acetic acetate buffer solutions or created with solutions of sulfuric acid and sodium hydroxide. The reagents used in the work were not lower than analytical reagent grade.

\subsection{Equipment}

Electronic absorption spectra were recorded on a spectrophotometer SF-56 (OKB "LOMO-Spectrum", RF) in cuvettes with the thickness of the absorbing layer $l=1$; 2; 3 and $5 \mathrm{~cm}$ in the wavelength range of 380-780 nm. The acidity of the medium was monitored by means of a glass electrode ESL-63-07 paired with a silver chloride reference electrode EVL-1M3 on an ionometer I-160, calibrated with standard buffer solutions.

\subsection{Optimization of Complex Formation Conditions}

To optimize the conditions for carrying out the complex formation reaction, aqueous solutions of $\mathrm{La}$ (III) and alizarin-complexone with a concentration in the range of $1 \cdot 10^{-5}-1 \cdot 10^{-4} \mathrm{~mol} \cdot \mathrm{dm}^{-3}$ were mixed in different molar ratios, in the $\mathrm{pH}$ range of $1-9$, and the absorbance was recorded. The stoichiometry of $\mathrm{La}(\mathrm{III})$ interaction products with alizarin-complexone, molar absorption coefficients and stability constants were established by standard methods. The composition of the mixed ligand complexes $\mathrm{La}$ (III) with alizarin-complexone and fluoride ions was established by the triple-diagram and saturation methods by the fluoride ion. Optimization of the geometry of the proposed complexes was carried out using molecular mechanics $\mathrm{MM}+$ methods in the software package HyperChemPro 6.

\subsection{Determination of Total Fluorine}

Approximately $0.5 \mathrm{~g}$ of toothpaste were weighed and placed in a flask, then $25 \mathrm{ml}$ of distilled water and $25 \mathrm{ml}$ of $0.5 \mathrm{~mol} \cdot \mathrm{dm}^{-3}$ perchloric acid were added. The flask was connected to a reflux condenser and heated in a boiling water bath for $1 \mathrm{~h}$. After cooling to a room temperature, the contents were filtered into a $100 \mathrm{ml}$ volumetric flask and diluted with distilled water. In the analysis of mouth rinses, an aliquot of the mouth rinse was taken, transferred to a $100 \mathrm{ml}$ flask and diluted with distilled water. To construct the calibration curve, $2 \mathrm{ml}$ of $\mathrm{La}$ (III) with the concentration of $1 \cdot 10^{-3} \mathrm{~mol} \cdot \mathrm{dm}^{-3}$ and $4 \mathrm{ml}$ of alizarin-complexone with the concentration of $1 \cdot 10^{-3} \mathrm{~mol} \cdot \mathrm{dm}^{-3}$ were used. Using an acetic acetate buffer, $1 \mathrm{ml}$ of Tween $80(\mathrm{pH}=5)$ was added; the solution was diluted to the mark with distilled water and heated for $15 \mathrm{~min}$ in a water bath at $333-343 \mathrm{~K}$. The solutions absorbance was measured at $620 \mathrm{~nm}$ relative to the blank solution $(2 \mathrm{ml}$ of $\mathrm{La}(\mathrm{III})$ solution at the concentration of $1 \cdot 10^{-3} \mathrm{~mol} \cdot \mathrm{dm}^{-3}, 4 \mathrm{ml}$ of alizarin-complexone at the concentration of $1 \cdot 10^{-3} \mathrm{~mol} \cdot \mathrm{dm}^{-3}, 1 \mathrm{ml}$ of Tween 80 with $\mathrm{pH}=5$ ) in a $5 \mathrm{~cm}$ cell. For spectrophotometric determination of $\mathrm{F}^{-}$from an analyte solution, an aliquot $(5 \mathrm{ml}$ for toothpastes) was transferred to a $50 \mathrm{ml}$ volumetric flask. $2 \mathrm{ml}$ of $\mathrm{La}(\mathrm{III})$ with the concentration of $1 \cdot 10^{-3} \mathrm{~mol} \cdot \mathrm{dm}^{-3}, 4 \mathrm{ml}$ of alizarin-complexone with the concentration of $1 \cdot 10^{-3} \mathrm{~mol} \cdot \mathrm{dm}^{-3}, 25 \mathrm{ml}$ of acetic acetate buffer and $1 \mathrm{ml}$ of Tween 80 were added and diluted with water to the mark. In the case of mouth rinses, an aliquot of 1.5-3.0 ml of mouth rinse was taken from the analyte solution and transferred to a $100 \mathrm{ml}$ volumetric flask. An aliquot of the resulting working solution $(5 \mathrm{ml})$ was taken. $2 \mathrm{ml}$ of La(III) with the concentration of $1 \cdot 10^{-3} \mathrm{~mol} \cdot \mathrm{dm}^{-3}$, $4 \mathrm{ml}$ of alizarin-complexone with the concentration of $1 \cdot 10^{-3} \mathrm{~mol} \cdot \mathrm{dm}^{-3}, 25 \mathrm{ml}$ of acetic acetate buffer and $1 \mathrm{ml}$ of Tween 80 were added and diluted with water to the mark.

The determination was carried out with the construction of the calibration graph. The concentration of $\mathrm{F}^{-}$was determined by the calibration chart or by the standard addition method and recalculated in weight percent. 


\section{Results and Discussion}

The absorption spectra of alizarin-complexone in aqueous solution and in the presence of $\mathrm{La}(\mathrm{III})$, fluoride and nonionic surfactant Tween 80 in a wide range of acidity of the medium and concentration of components were studied. Fig. 1 shows the absorption spectra of the systems under study.

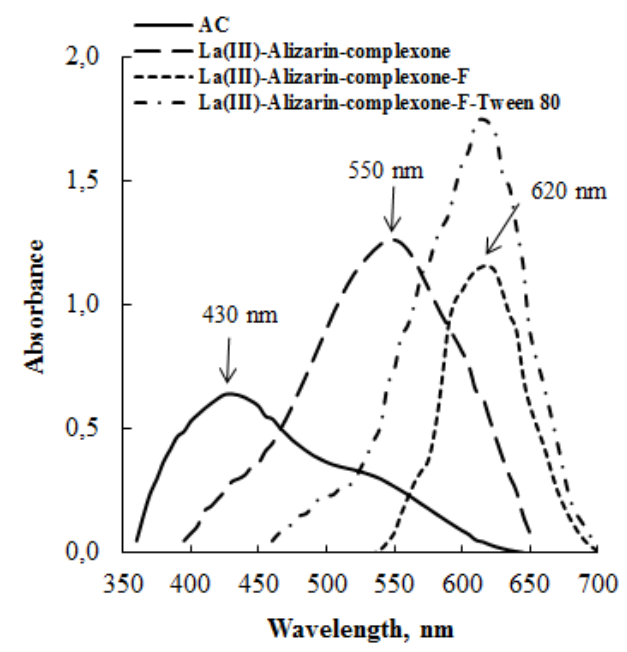

Fig. 1. Absorption spectra of the investigated systems.

$$
\begin{gathered}
C_{\mathrm{La}(\text { III })}=4 \cdot 10^{-5} \mathrm{M} ; C_{\text {alizarin-complexone }}=8 \cdot 10^{-5} \mathrm{M} ; \\
C_{F}=1 \cdot 10^{-6} \mathrm{M} ; l=5 \mathrm{~cm}
\end{gathered}
$$

The absorption spectrum of alizarin-complexone with $\mathrm{pH} 5$ has one wide absorption band at $\lambda_{\max }=430 \mathrm{~nm}$. When the $\mathrm{La}$ (III)- alizarin-complexone complex is formed at $\mathrm{pH}$ 5.5, a hyperchromic and bathochromic shift of the absorption band at $120 \mathrm{~nm}$ is observed $\left(\lambda_{\max }=550 \mathrm{~nm}\right)$. In turn, the addition of fluorides leads to a bathochromic shift of the absorption band at $70 \mathrm{~nm}$, which may indicate the formation of a mixed ligand complex. The introduction of a non-ionic surfactant Tween 80 into the system results in a significant increase in light absorption

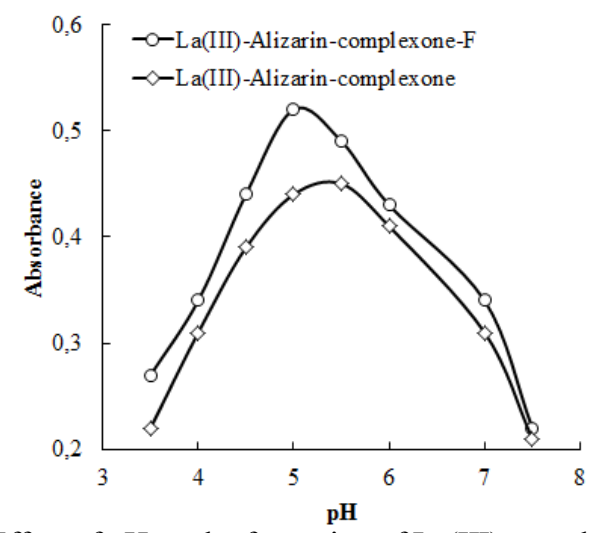

Fig. 2. Effect of $\mathrm{pH}$ on the formation of $\mathrm{La}$ (III) complexes with alizarine-complexone and fluoride ions; $C_{\mathrm{La}(\mathrm{III})}=4 \cdot 10^{-5} \mathrm{M}$; $C_{\text {alizarin-complexone }}=8 \cdot 10^{-5} \mathrm{M} ; C_{F}=8 \cdot 10^{-5} \mathrm{M} ; l=2 \mathrm{~cm}$ at $620 \mathrm{~nm}$. The maximum absorption is observed at the concentration of Tween 80 in a solution of $0.02 \mathrm{mmol} / \mathrm{l}$, which is 1.5 times higher than the critical micelle concentration [19]. Thus, the system undergoes solubilization of the multigligand complex in the Tween 80 micelles, which leads to dispersion of the particles in the solution, increasing the stability of the analytical form and increasing its molar absorptivity, but does not affect the position of the absorption maximum.

As can be seen from Fig. 2, the maximum light absorption is observed at $\mathrm{pH}$ 5.5. For convenience, $\mathrm{pH} 5.5$ was then maintained with an acetic acetate buffer solution.

The optimal conditions for the production of the triple lanthanum-alizarin-complexon-fluoride complex is pH 5 (Fig. 2) and $15 \mathrm{~min}$ of heating in a water bath at 333-343 K (Fig. 3). At higher temperatures, a decrease in the absorption intensity of the ligand complex is observed, which is probably related to its destruction.

To determine the composition of the complexes in the La(III)- alizarin-complexone system, classical spectrophotometric methods were used: isomolar series, ligand and metal saturation, equilibrium shift, and the Harvey-Menning slope ratio. For example, Fig. 4 shows the graphical dependencies of the determination of the composition of the complex by the Asmus method and the equilibrium shift. Analysis of the graphical dependences shown in Fig. 4, as well as other methods listed above, allow us to state that at $\mathrm{pH} 5.5$ in the $\mathrm{La}(\mathrm{III})$-alizarincomplexone system, one moderately stable $1: 2$ complex is formed. The composition of the mixed ligand complexes was established by the triple-diagram method and the modified isomolar series method. It is established that two complexes are formed in the system $\mathrm{La}$ (III):alizarincomplexone: $\mathrm{F}^{-}$of composition 1:2:1 and 1:2:2, respectively. To confirm the stepwise character of the complex formation, the ligand saturation method was used. Thus, taking the ratio of La:alizarin-complexone as constant, saturation curves were obtained (Fig. 5).

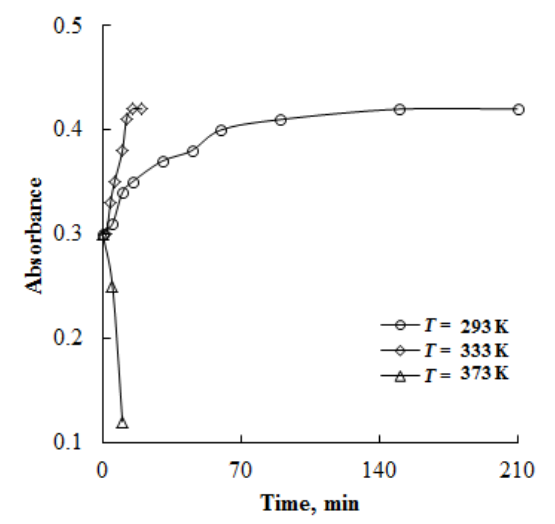

Fig. 3. Effect of temperature and time on the light absorption of a mixed ligand complex. $C_{\mathrm{La}(\mathrm{III})}=4 \cdot 10^{-5} \mathrm{M}$; $C_{\text {alizarin-complexone }}=8 \cdot 10^{-5} \mathrm{M} ; C_{F}=6 \cdot 10^{-5} \mathrm{M} ; l=2 \mathrm{~cm}$ 

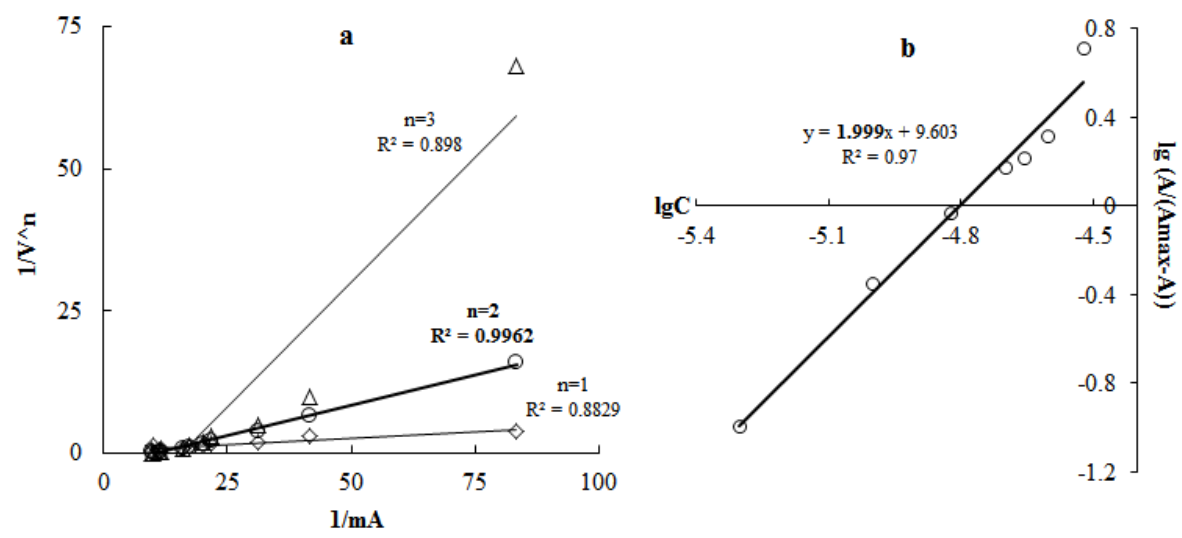

Fig. 4. Determination of the composition of the Lanthanum-alizarine-complexone complex by different methods: the straight line of Asmus (a); equilibrium shifts (b). $C_{\mathrm{La}(I I)}=4 \cdot 10^{-5} \mathrm{M}$;

$C_{\text {alizarin-complexone }}=8 \cdot 10^{-5} \mathrm{M} ; l=2 \mathrm{~cm}$

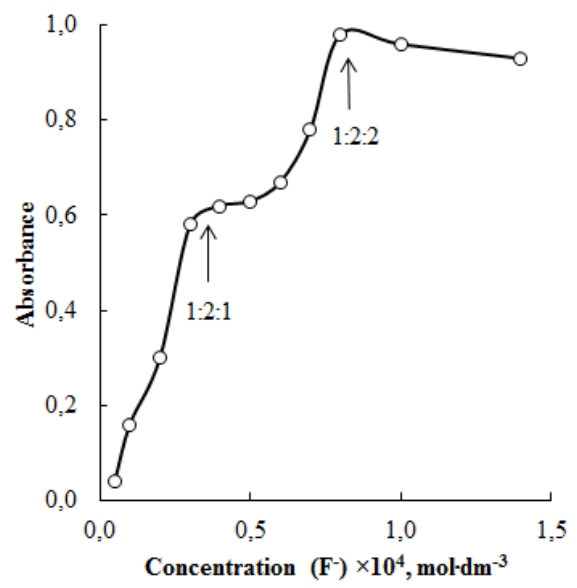

Fig. 5. Saturation in fluoride of alizarin-lanthanum complexonate.

$$
\begin{gathered}
C_{\mathrm{La}(I I I)}=4 \cdot 10^{-5} \mathrm{M} ; C_{\mathrm{AC}}=8 \cdot 10^{-5} \mathrm{M} ; C_{\mathrm{La}(I I I)} \\
\mathrm{C}_{\text {alizarin-complexone }}=1: 2=\text { const } l=3 \mathrm{~cm}
\end{gathered}
$$

Analytical characteristics of alizarin-complexone complexes

\begin{tabular}{|c|c|c|c|}
\hline La(III): alizarin-complexone:F (molar ratio) & $\lambda, \mathrm{nm}$ & $\varepsilon, \mathrm{mol} \cdot \mathrm{dm}^{-3} \cdot \mathrm{cm}^{-1}$ & $\beta \cdot 10^{-9}$ \\
\hline $1: 2$ & 550 & 9500 & 1.6 \\
\hline $1: 2: 1$ & 620 & 7600 & 2.6 \\
\hline $1: 2: 1^{*}$ & 620 & 11000 & 2.9 \\
\hline $1: 2: 2$ & 620 & 6100 & 3.1 \\
\hline
\end{tabular}

Note: ${ }^{*}$ in the presence of nonionic surfactant Tween 80 .

It can be seen that complexes with fluoride are formed: at first with the composition of 1:2:1, and then 1:2:2. The main chemical-analytical characteristics of complex formation products are summarized in Table 1.

According to the data of Table 1, as an analytical form for the determination of $\mathrm{F}^{-}$, it is rational to use a mixed ligand complex of 1:2:1 composition, which is characterized by a high molar absorption coefficient. The limits of determination $(10 \sigma)$ and detection $(3 \sigma)$ are equal to $5.2 \cdot 10^{-6} \mathrm{~mol}^{-1 \mathrm{dm}^{-3}}(0.10 \mu \mathrm{g} / \mathrm{ml})$ and $1.7 \cdot 10^{-6} \mathrm{~mol} \cdot \mathrm{dm}^{-}$ ${ }^{3}(0.03 \mu \mathrm{g} / \mathrm{ml})$, respectively. The limit for the detection of fluorides in the form of a mixed ligand complex of $\mathrm{La}$ (III) with alizarin-complexone varies in the range of $0.06-$ $0.20 \mu \mathrm{g} / \mathrm{ml}$. For example, in the procedure [20] this value 
is about $0.06 \mu \mathrm{g} / \mathrm{ml}$. Thus, the reaction in a micellar medium allows reducing LOD without the introduction of toxic organic solvents, which corresponds to the principles of "green chemistry".
Based on the studies carried out and according to the information on the state of the reagents in aqueous solutions [21], the following interaction scheme in the systems under study can be proposed (Fig. 6).
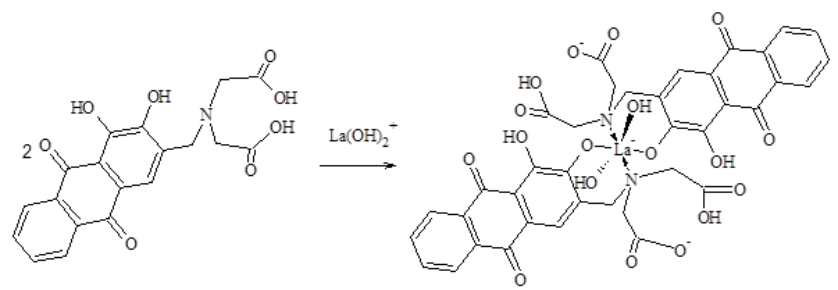

$-\mathrm{OH}^{-} \mid+\mathrm{F}^{-}$
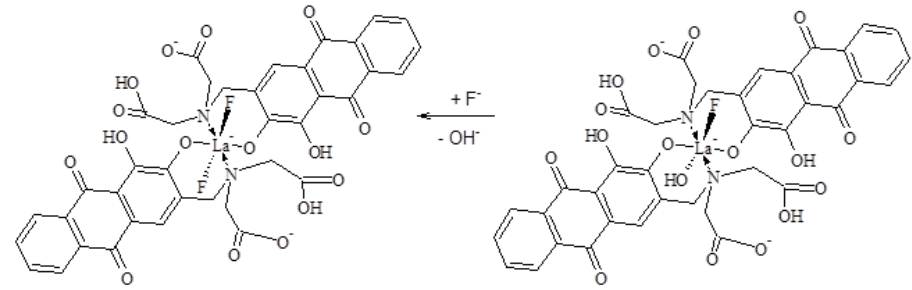

Fig. 6. Scheme of interaction in the system under study

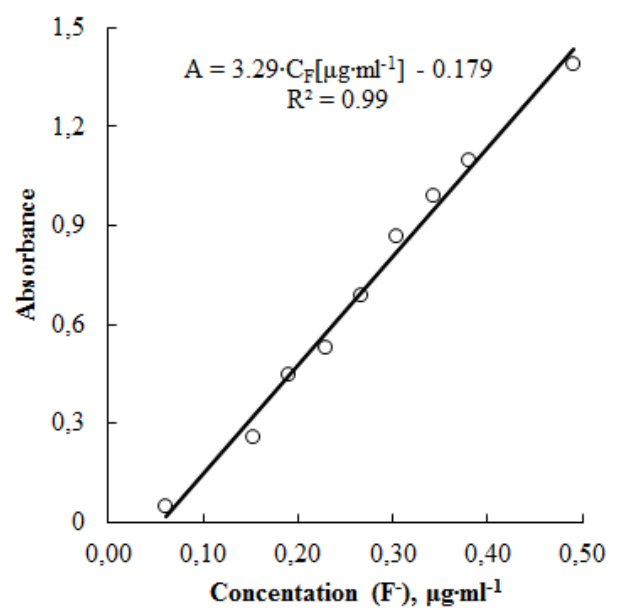

Fig. 7. Calibration chart for determination of fluoride ion. $C_{\mathrm{La}(I I I)}=4 \cdot 10^{-5} \mathrm{M}$;

$$
C_{\text {alizarin-complexone }}=8 \cdot 10^{-5} \mathrm{M} ; l=5 \mathrm{~cm}
$$

Determination of fluorides in oral hygiene products

\begin{tabular}{|c|c|c|c|c|c|}
\hline \multicolumn{2}{|c|}{ Analyzed product } & \multicolumn{3}{|c|}{ Found experimentally, \% (Relative standard deviation) } & $\begin{array}{l}\text { Specified by the } \\
\text { manufacturer, } \%\end{array}$ \\
\hline \multirow{3}{*}{ Toothpastes } & Sample 1 & $0.1458 \pm 0.009 *(0.05)$ & $0.1453 \pm 0.005 * *(0.03)$ & $0.1448 \pm 0.009 * * *(0.05)$ & 0.145 \\
\hline & Sample 2 & $0.1442 \pm 0.008 *(0.05)$ & $0.1422 \pm 0.007 * *(0.04)$ & $0.1432 \pm 0.009 * * *(0.05)$ & 0.145 \\
\hline & Sample 3 & $0.1444 \pm 0.007 *(0.04)$ & $0.1449 \pm 0.009 * *(0.05)$ & $0.1441 \pm 0.005 * * *(0.03)$ & 0.145 \\
\hline \multirow{3}{*}{ Mouth rinses } & Sample 1 & $0.0223 \pm 0.001 *(0.04)$ & $0.0225 \pm 0.001 * *(0.04)$ & $0.0222 \pm 0.001 * * *(0.05)$ & 0.0225 \\
\hline & Sample 2 & $0.033 \pm 0.001 *(0.04)$ & $0.034 \pm 0.001 * *(0.04)$ & $0.035 \pm 0.001 * * *(0.04)$ & 0.033 \\
\hline & Sample 3 & $0.045 \pm 0.003 *(0.05)$ & $0.044 \pm 0.002 * *(0.03)$ & $0.043 \pm 0.002 * * *(0.04)$ & 0.045 \\
\hline
\end{tabular}

Notes: * according to the calibration curve; ** standard addition method; *** according to the ISO 11609:2017 Dentistry Dentifrices - Requirements, test methods and marking. 
Based on the recommended analytical form, a method for spectrophotometric determination of $\mathrm{La}$ (III) with alizarin-complexone in toothpastes and mouth rinses has been developed. The influence of foreign ions on the mixed ligand complex absorbance was studied and it was established that ions of $\mathrm{Na}^{+}$and $\mathrm{K}^{+}$do not interfere with the fluoride determination. A number of other ions interfere with fluorides determination in the following ratios: $1: 1000\left(\mathrm{Ca}^{2+}\right.$ and $\left.\mathrm{Mg}^{2+}\right) ; 1: 250\left(\mathrm{HCO}_{3}{ }^{-}\right) ; 1: 100\left(\mathrm{Cl}^{-}\right.$, $\mathrm{Br}) ; 1: 50\left(\mathrm{HPO}_{4}{ }^{2-}\right)$. The calibration curve (Fig. 7) is linear in the concentration range of $0.06-0.5 \mu \mathrm{g} / \mathrm{ml}$.

The proposed method was tested on 3 commercial toothpastes and 3 mouth rinses. Correctness of the results was verified by the standard addition method. The results obtained are summarized in Table 2. The developed procedure for determination of fluorides is characterized by a low relative error of determination, not exceeding $5 \%$.

\section{Conclusions}

It was found that at $\mathrm{pH} 5.5, \mathrm{La}(\mathrm{III})$ forms one complex with alizarin-complexone of composition 1:2 $\left(\lambda=550 \mathrm{~nm}, \varepsilon=9500 \mathrm{~mol} \cdot \mathrm{dm}^{-3} \cdot \mathrm{cm}^{-1}, \beta=1.6 \cdot 10^{9}\right) . \mathrm{La}(\mathrm{III})$, alizarin-complexone and fluoride ion stepwise form two mixed ligand complexes of 1:2:1 composition $\left(\varepsilon_{620}=7600 \mathrm{~mol} \cdot \mathrm{dm}^{-3} \cdot \mathrm{cm}^{-1}, \beta=2.6 \cdot 10^{9}\right)$ and $1: 2: 2$ $\left(\varepsilon_{620}=6100 \mathrm{~mol} \cdot \mathrm{dm}^{-3} \cdot \mathrm{cm}^{-1}, \beta=3.1 \cdot 10^{9}\right)$. It is shown that as an analytical form it is expedient to use the La:alizarincomplexone: $\mathrm{F}^{-}=1: 2: 1$ complex, which in the presence of Tween 80 is characterized by the molar absorptivity $\varepsilon_{620}=11000 \mathrm{~mol} \cdot \mathrm{dm}^{-3} \cdot \mathrm{cm}^{-1}$, and the detection and determination limits of $5.2 \cdot 10^{-6} \mathrm{~mol} \cdot \mathrm{dm}^{-3}(0.10 \mu \mathrm{g} / \mathrm{ml})$ and $1.7 \cdot 10^{-6} \mathrm{~mol} \cdot \mathrm{dm}^{-3}(0.03 \mu \mathrm{g} / \mathrm{ml})$, respectively. The calibration curve is linear in the concentration range of fluoride ions $(0.06-0.5) \mu \mathrm{g} / \mathrm{ml}$. A simple, rapid and sensitive procedure for the spectrophotometric determination of $\mathrm{F}^{-}$ using alizarin - lanthanum complexonate in the presence of Tween 80 was developed, which was tested on samples of toothpastes and mouth rinses.

\section{References}

[1] René A., Rocha R., Rojas D. et al.: J. Agric. Food Chem., 2013, 61,10708. https://doi.org/10.1021/jf403728r

[2] Švarc-Gajić J., Stojanović Z., Vasiljević I., Kecojević I.: J. Food Drug Anal., 2013, 21, 384.

https://doi.org/10.1016/j.jfda.2013.08.006

[3] Amanlou M., Hosseinpour M., Azizian H. et al.: Iran. J. Pharm. Res., 2010, 9, 37.

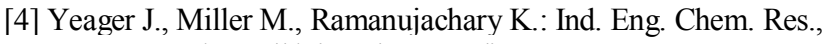
2006, 45, 4525. https://doi.org/10.1021/ie060128a

[5] Rajković M., Novaković I.: J. Agricult. Sci., 2007, 52, 155.

[6] Marczenko Z., Balcerzak M.: Spektrofotometryczne Metody w Analizie Nieorganicznej. Wydawnictwo Naukowe PWN, Warszawa 1998.
[7] Adelantado J., Martinez V., Moreno A., Reig F.: Talanta, 1985, 32, 224. https://doi.org/10.1016/0039-9140(85)80067-9

[8] Lili Z., Xiaohong Z., Shikang W.: Chem. Lett., 2004, 33, 850. https://doi.org/10.1246/cl.2004.850

[9] Hu J., Whittaker M., Davis T., Quinn T.: ACS Macro Lett., 2015, 4, 236. https://doi.org/10.1021/mz500782r

[10] Kumar S., Luxami V., Kumar A.: Org. Lett., 2008, 10, 5549. https://doi.org/10.1021/ol802352j

[11] Barghouthi Z., Amereih S.: Am. J. Anal. Chem., 2012, 3, 651. https://doi.org/10.4236/ajac.2012.39085

[12] Pillai A., Varghese B., Madhusoodanan K.: Environ. Sci. Technol., 2012, 46, 404. https://doi.org/10.1021/es2028718

[13] Zhou X., Lai R., Li H., Stains C.: Anal. Chem., 2015, 87, 4081. https://doi.org/10.1021/acs.analchem.5b00430

「14] Amano O., Sasahira A., Kani Y. et al.: J. Nucl. Sci. Technol., 2004, 41, 55. https://doi.org/10.1080/18811248.2004.9715457

[15] Hall A., Walsh J.: Anal. Chim. Acta, 1969, 45, 341.

https://doi.org/10.1016/S0003-2670(01)95608-9

[16] Paustovska A., Zinko L., Zaporozhets O. et al.: Methods Objects Chem Anal., 2015, 10, 53.

[17] Shtykov S.: J. Anal. Chem., 2000, 55, 608. https://doi.org/10.1007/BF02827992

[18] Schwarzenbach G., Flaschka H.: Die komplexometrische Titration. Ferdinand Enke, Stuttgart 1965.

[19] Holmberg K., Jönsson B., Kronberg B., Lindman B.:

Surfactants and Polymers in Aqueous Solution. John Wiley \& Sons, Ltd, Chichester 2002.

[20] Quintana M., Blanco M., Lacal J., Hernández L.: Talanta, 2003, 59, 417. https://doi.org/10.1016/S0039-9140(02)00519-2 [21] Chebotarev A., Snigur D., Bevziuk K.: Izv. Vyssh. Uchebn. Zaved. Khim. Khim. Tekhnol. 2017, 60, 22.

https://doi.org/10.6060/tcct.2017603.5418

Received: April 19, 2018 / Revised: June 05, 2018 / Accepted: September 15, 2018

\section{ЗМІШАНОЛІГАНДНИЙ КОМПЛЕКС ЛАНТАНУ(ІІІ) І АЛІЗАРИН-КОМПЛЕКСОНУ 3 ФЛУОРИДОМ В МШЕЛЯРНОМУ СЕРЕДОВИЩІ ДЛЯ СПЕКТРОФОТОМЕТРИЧНОГО ВИЗНАЧЕННЯ ЗАГАЛЬНОГО ФЛУОРУ}

Анотація. Розроблені методики прямого спектрофотометричного визначення загального флуору у продуктах для гігієни порожнини рота з використанням змішанолігандного комплексу La(III) та алізарин-комплексону з флуоридйонами у присутності нейонної поверхнево-активної речовини. Встановлено, шуо у системі утворюється ряд комплексів різної стехіометрії та показано, щзо як аналітичну форму дочільно використовувати комплекс складу Lа:алізарин-комплексон:F $=1: 2: 1$, який у присутності Twеen 80 характеризується молярним коефіиієнтом поглинання $\varepsilon_{620}=11000$ моль $\cdot \mathrm{\nu M}^{-3} \cdot \mathrm{cM}^{-1}$. Показано, щчо калібрувальний графік $є$ лінійним в діапазоні концентрачій флуорид-йонів 0,06-0,5 мкг/мл. Запропоновано просту, швидку та чутливу методику для спектрофотометричного визначення $F$ з використанням алізарин-комплексонату лантану в присутності Tween 80, яку було апробовано на зразках зубних паст та ополіскувачах ротової порожнини.

Ключові слова: спектрофотометрія, алізаринкомплексон, змішанолігандний комплекс, флуор, Tweеn 80. 